\title{
PELAKSANAAN SITA JAMINAN TERHADAP OBJEK SENGKETA YANG BERADA DI TANGAN PIHAK KETIGA DALAM PENANGANAN PERKARA PERDATA
}

\author{
Mhd. Teguh Syuhada Lubis \\ Fakultas Hukum Universitas Muhammadiyah Sumatera Utara \\ Jl. Kapt. Mukhtar Basri Nomor 3, Medan - Sumatera Utara \\ Email: mhdteguhsyuhada@umsu.ac.id
}

\begin{abstract}
Abstrak
Hukum Acara Perdata mengatur lembaga yang disebut penyitaan properti (conservatoir beslag) yang diatur dalam Pasal 261 RBG atau 227 Ayat (1) HIR. Pasal 261 RBG menjelaskan sebagai berikut: Jika ada alasan yang masuk akal, bahwa seseorang berhutang, sebelum keputusan dibuat, atau sebelum putusan yang mengalahkannya tidak dapat dilaksanakan, tetapi untuk memberikan kepastian dan rasa keadilan bagi pihak-pihak dalam perkara perdata peran lembaga diperlukan jaminan penyitaan. Lembaga penyitaan dianggap mampu menjaga barang yang disengketakan dari tindakan terdakwa sehingga dapat menjamin kepentingan penggugat dapat dilindungi. Dalam praktiknya, jaminan penyitaan dalam gugatan tersebut diberikan oleh hakim dan dinyatakan sah dan bernilai akan secara otomatis menjadi penyitaan eksekusi untuk mendukung keputusan. Pihak-pihak yang berkepentingan dengan hak-hak objek yang disengketakan dalam gugatan perdata harus, atas permintaan orang yang bersangkutan, Ketua Pengadilan Distrik memberikan perintah untuk menyita objek sengketa untuk dijaga. Dalam praktiknya, jaminan penyitaan tidak selalu berjalan dengan baik, terutama untuk penyitaan agunan, di mana objek sengketa berada di tangan pihak ketiga, sehingga pentingnya meninjau proses penyitaan ada di tangan pihak ketiga dalam objek tersebut. penanganan kasus perdata.
\end{abstract}

\section{Kata Kunci: Sita, Jaminan, Pihak, Objek, Sengketa}

\section{Abstract}

Civil procedure Code regulates an institution called the seizure of property (conservatoir beslag) which is regulated in Article 261 RBG or 227 Paragraph (1) HIR. Article 261 The $R B G$ explains as follows: If there are reasonable grounds, that a person is in debt, before the decision is made, or before the verdict that defeats it cannot be implemented, but in order to provide certainty and a sense of justice for the parties in the civil case the role of the institution is needed confiscation guarantee. The confiscation institution is considered able to keep the disputed goods from the defendant's actions so that it can guarantee the plaintiff's interests can be protected. In practice the seizure guarantee in the lawsuit is granted by the judge and declared valid and valuable will automatically become executorial seizure in order to support the decision. Parties with an interest in the rights of the object disputed in a civil suit shall, at the request of the person concerned, the Chairperson of the District Court give the order to confiscate the object of the dispute in order to safeguard. In practice, seizure guarantees do not always go well, especially for collateral seizure, where the object of the dispute is in the hands of a third party, so that the importance of reviewing the confiscation process is in the hands of third parties in the object of handling civil cases.

Keywords: Seizure, Security, Third, Object, Dispute 
DE LEGA LATA

Jurnal Ilmu Hukum

FAKULTAS HUKUM UMSU
Pelaksanaan Sita Jaminan...(Mhd. Teguh Syuhada Lubis)

Volume 4 Nomor 1, Januari-Juni 2019, 42-53 DOI: https://doi.org/10.30596/dll.v4i1.3163

\section{PENDAHULUAN}

Hubungan antara manusia dengan manusia dalam praktik sehari-hari seringkali dapat menimbulkan hubungan hukum, yang mana dalam hubungan tersebut anatara yang satu dengan yang lainnya akan menimbulkan hak dan kewajiban yang harus dipenuhi oleh para pihak sehingga dalam istilah hukum dikenal hukum perdata materil dan hukum perdata formil. Hukum perdata materil adalah suatu kumpulan dari pada peraturan perundangundangan yang mengatur tentang hak dan kewajiban keperdataan (privat) antara pihak yang satu dengan pihak lainnya, sedangkan hukum perdata formil adalah peraturan perundangundangan yang mengatur tentang pelaksanaan sanksi hukuman terhadap para pelanggar hakhak keperdataan sesuai dengan hukum perdata materil mengandung sanksi yang sifatnya memaksa (Sarwono, 2011, h. 3-4).

Hukum acara perdata positif yang masih berlaku hingga saat ini adalah RBG dan HIR, khusus diluar Jawa dan Madura seperti kita yang ada di Sumatera berlaku penuh ketentuan RBG sebagai hukum acara perdata positif, sesuai dengan ketentuan Aturan Peralihan Pasal II dan IV Undang-Undang Dasar Republik Indonesia tanggal 18 Agustus 1945. Namun RBG dan HIR tidaklah merupakan aturan yang lengkap yang mampu mencakup semua ruang lingkup hukum acara perdata positif di Indonesia. Peraturan-peraturan yang melengkapi RBG dan HIR contohnya antara lain: Undang-Undang Nomor 14 Tahun 1970 juncto UndangUndang Nomor 4 Tahun 2004 tentang Pokok-Pokok Kekuasaan Kehakiman, Undang-Undang Nomor 20 Tahun 1947 tentang Banding (hanya berlaku untuk daerah Jawa dan Madura), Undang-Undang Nomor 2 Tahun 1986 tentang Pengadilan Dalam Lingkungan Peradilan Umum, Undang-Undang Nomor 14 Tahun 1985 tentang Mahkamah Agung, Undang-Undang Nomor 1 Tahun 1974 tentang Perkawinan, R.V. (Reglement of de Burgerlijke Rechtsvordering), yang dinyatakan tidak berlaku lagi, namun dalam prakteknya dua aturan ini masih dijadikan acuan pelengkap bila ada aturan-aturan yang tidak jelas (Retnowulan Sutanto, 2009, h. 6).

Para pihak yang mengajukan tuntutan hak ke pengadilan tentunya akan beracara sesuai hukum acara perdata yang berlaku mulai dari pengajuan tuntutan hak sampai jatuhnya putusan pengadilan. Tentunya para pihak tidak hanya mengharap putusan pengadilan semata yang berisi penyelesaian perkara yang diselesaikan dimana didalamnya ditentukan dengan pasti hak maupun hubungan hukum para pihak dengan objek yang dipersengketakan (M. Yahya Harahap, 2008, h. 797). Namun sudah pasti putusan tersebut mempunyai kekuatan eksekusi sehingga putusan pengadilan tersebut dapat dilaksanakan seluruhnya sehingga tercapai apa yang disebut Rule of Law atau demi tegaknya hukum dan keadilan.

Putusan tidak ada artinya apabila tidak dapat dilaksanakan. Oleh karena itu putusan hakim mempunyai kekuatan eksekutorial yaitu berkekuatan untuk dilaksanakan sesuai dengan apa yang ditetapkan dalam putusan itu secara paksa oleh alat-alat negara. Walaupun putusan pengadilan itu dapat dilakukan dan mempunyai kekuatan eksekutorial, tetapi banyak pihak yang masih merasa khawatir bahwa selama proses persidangan berlangsung tergugat akan menjual barang-barangnya atau dengan jalan lain mengalihkan hak atas barangnya, sehingga 
Jurnal Ilmu Hukum

FAKULTAS HUKUM UMSU
Pelaksanaan Sita Jaminan...(Mhd. Teguh Syuhada Lubis)

Volume 4 Nomor 1, Januari-Juni 2019, 42-53 DOI: https://doi.org/10.30596/dll.v4i1.3163

jika waktunya telah tiba putusan telah mempunyai kekuatan hukum yang tetap dan hendak dilaksanakan, barang yang menjadi objek persengketaan tidak dapat dieksekusi karena barang tersebut tidak berada ditangan tergugat lagi atau berada ditangan pihak ketiga yang tentunya sangat merugikan bagi pihak penggugat.

Hukum acara perdata diatur sebuah lembaga yang bernama Lembaga Sita Jaminan (conservatoir beslag) yang diatur dalam Pasal 261 RBG atau 227 ayat 1 Herzien Inlandsch Reglement (HIR). Pasal 261 RBG menjelaskan sebagai berikut: Jika ada persangkaan yang beralasan, bahwa seorang berhutang, sebelum dijatuhkan putusan atasnya, atau sebelum putusan yang mengalahkannya belum dapat dijalankan, berdaya upaya akan menghilangkan atau membawa barangnya yang bergerak ataupun yang tidak bergerak, dengan maksud menjauhkan barang itu dari para penagih hutang, maka atas permintaan orang yang berkepentingan Ketua Pengadilan Negeri dapat memberikan perintah supaya disita barang itu akan menjaga hak memasukkan permintaan itu, selain daripada itu kepada orang yang meminta diberitahukan pula, bahwa ia akan menghadap pada persidangan Pengadilan Negeri yang akanditentukan, seboleh-bolehnya dalam persidangan yang pertama akan datang untuk menyebut dan meneguhkan gugatan (Retnowulan Sutanto, 2009, h. 472).

Di dalam prakteknya sita jaminan yang dalam gugatan dikabulkan oleh hakim dan dinyatakan sah dan berharga otomatis akan menjadi sita eksekutorial dalam rangka mendukung putusan tersebut. Namun tidak semua putusan hakim dapat dilaksanakan secara sebenar-benarnya yaitu secara paksa oleh pengadilan. Hanya putusan yang bersifat condemnatoir sajalah yang dapat dilaksanakan, sedangkan putusan yang bersifat declaratoir dan consitutif tidak memerlukan sarana-sarana pemaksa untuk melaksanakannya (Retnowulan Sutanto, 2009, h. 109).

Secara yuridis, pengertian sita jaminan adalah sita yang merupakan upaya hukum yang diambil oleh Pengadilan sebagai tindakan yang mendahului pemeriksaan pokok perkara ataupun mendahului putusan. Jadi sita jaminan dapat dilakukan sebelum pengadilan memeriksa pokok perkara atau pada saat proses pemeriksaan perkara sedang berjalan, sebelum Majelis Hakim (Pengadilan) menjatuhkan putusan (R. Soeparmono, 2006, h. 40).

Berdasarkan uraian tersebut diatas hakim sekali lagi harus teliti dalam memeriksa suatu permohonan sita jaminan. Para hakim harus benar- benar melihat suatu permohonan sita jaminan secara utuh dan menyeluruh tidak hanya melihat syarat dan pertimbangan hukumnya saja tetapi harus melihat fakta yang ada di lapangan agar putusan nanti dapat dilaksanakan dan mencerminkan rasa keadilan bagi para pihak.

Perkara pelunasan hutang kadang-kadang di dalam waktu pelaksanaan sita jaminan ada pihak ketiga yang mengaku bahwa barang yang disengketakan tersebut adalah miliknya. Sehingga pelaksanaan sita jaminan dalam beberapa perkara kasus objek yang hendak disita merupakan warisan yang belum terbagi waris dan pihak ketiga tersebut merupakan ahli waris yang berhak pula atas barang yang disita. Sehingga kepentingan hukum atas barang tersebut terganggu dengan adanya sita jaminan tersebut. Di dalam pelaksanaan di tempat barang tersebut berada belum tentu berjalan mulus. 
Jurnal Ilmu Hukum

FAKULTAS HUKUM UMSU

Sita jaminan yang berada di tangan pihak ketiga dapat menjadi alasan bahwa pentingnya mengkaji lebih dalam proses pelaksanaan sita jaminan yang berada di tangan pihak ketiga dalam objek penanganan perkara perdata maka penulis tertarik untuk menuangkan dalam bentuk tulisan ini dengan judul Pelaksanaan Sita Jaminan Terhadap Objek Sengketa Yang Berada di Tangan Pihak Ketiga Dalam Penaganan Perkara Perdata.

\section{METODE PENELITIAN}

Penelitian ini merupakan penelitian hukum. Penelitian hukum adalah penelitian yang diterapkan atau diberlakukan khusus pada ilmu hukum (Istanto, 2007, h. 29). Penelitian ini merupakan penelitian hukum yang bertujuan untuk mencari jawaban atau solusi dari fokus permasalahan yang diteliti sehingga dapat menjadi referensi untuk perubahan dibidang hukum yang lebih baik. Jenis penelitian ini menggunakan penelitian pustaka, penelitian pustaka merupakan penelitian yang mencari data yang terkait dengan permasalahan yang diteliti lalu akan dirangkum dengan baik untuk kemudian dapat diketahui apa yang menjadi permasalahan dan apa yang dapat menjadi jawaban serta solusinya. Penulis menggunakan pendekatan perundang-undangan, filosofis, serta konseptual dalam penelitian ini. Analisis data yang digunakan adalah analisis kualitatif yang memadukan data dari beberapa sumber menajdi uraian kalimat yang mudah dibaca dan dipahami.

\section{PEMBAHASAN}

\section{Pengaturan Sita Jaminan Terhadap Objek Sengketa Yang Berada Di Tangan Pihak Ketiga Dalam Penanganan Perkara Perdata}

Sita jaminan atau Conservatoir beslag diatur dalam Pasal 227 ayat 1 HIR, Pasal 261 Ayat 1 Rechtreglement voor de Buitengewesten (RBG), atau Pasal 720 Reglement op de Rechtvordering (Rv) adalah menyita barang debitur selama belum dijatuhkan putusan dalam perkara tersebut, tujuannya agar barang itu tidak digelapkan atau diasingkan tergugat selama proses persidangan berlangsung, sehingga pada saat putusan dilaksanakan, pelunasan pembayaran utang yang di tuntut penggugat dapat terpenuhi, dengan jalan menjual barang sitaan itu.

Bertitik tolak dari penggarisan Pasal 277 ayat $1 \mathrm{HIR}$, pelaksanaan sita jaminan pada dasarnya hanya terbatas pada sengketa perkara utang-piutang yang ditimbulkan oleh wanprestasi. Dengan diletakkannya sita pada barang milik tergugat, barang itu tidak dapat dialihkan tergugat kepada pihak ketiga, sehingga tetap utuh sampai putusan berkekuatan hukum tetap. Apabila tergugat tidak memenihi pembayaran secara sukarela, pelunasan ganti rugi itu, diambil secara paksa dari barang sitaan melalui penjualan lelang. Dengan demikian, tindakan penyitaan barang milik tergugat sebagai debitur dimaksudkan: (M. Yahya Harahap, 2008, h. 322)

a. Bukan untuk diserahkan dan dimiliki penggugat (pemohon sita)

b. Tetapi di peruntukkan melunasi pembayaran utang tergugat kepada penggugat.

Seperti yang dijelaskan, dalam arti sempit berdasarkan Pasal 227 ayat 1 HIR, sita jaminan hanya dapat diterapkan dalam perkara utang-piutang. Akan tetapi dalam praktik, 
DEIFGA LATA

Jurnal Ilmu Hukum

FAKULTAS HUKUM UMSU
Pelaksanaan Sita Jaminan...(Mhd. Teguh Syuhada Lubis)

Volume 4 Nomor 1, Januari-Juni 2019, 42-53

DOI: https://doi.org/10.30596/dll.v4i1.3163

pelaksanaan diperluas meliputi sengketa tuntutan ganti rugi baik yang timbul dari:

a. Wanprestasi berdasarkan Pasal 1243 jo. Pasal 1247 KUHPerdata dalam bentuk penggantian biaya, bunga dan keuntungan yang akan diperoleh, atau

b. Perbuatan melawan hukum (PMH) berdasarkan Pasal 1365 KUHPerdata dalam bentuk ganti rugi materill dan imaterill.

Penjaminan pemenuhan pembayaran tuntutan ganti rugi yang diajukan penggugat berdasarkan wanprestasi atau PMH, dapat meminta kepada pengadilan agar diletakkan sita jaminan terhadap barang milik tergugat. Dengan demikian, praktik pengadilan telah memperluas (extend) penafsiran utang meliputi ganti rugi, sehingga terhadap sengketa yang demikian dapat dibenarkan untuk menerapkan sita jaminan yang diatur Pasal 227 ayat 1 HIR atau Pasal 720 RV, perluasan pelaksanaan tersebut bertitik tolak dari rasio, bahwa elemen pokok tuntutan utang, pada dasarnya sama dengan tuntutan ganti rugi. Sama-sama berbentuk pemenuhan pembayaran prestasi berupa uang kepada penggugat.

Sita jaminan ternyata telah di perluas juga meliputi segketa hak milik atas benda tidak bergerak. Perluasan ini dianggap perlu, karena sita revindikasi yang diatur dalam Pasal 226 HIR tidak mencakup sengketa hak milik atas barang tidak bergerak, akan terdapat kekosongan hukum, sehingga tidak mungkin melindungi penggugat atas tindakan tergugat yang beriktikad buruk selama proses persidangan berlangsung, tergugat leluasa menjual atau memindahtangankan barang itu kepada pihak ketiga tanpa ancaman hukuman jika tidak diletakkan sita jaminan terhadapnya. Sehubungan dengan gambaran kekosongan hukum tersebut, cukup alasan menerima perluasan pelaksanaan sita jaminan meliputi sengketa milik atas barang tidak bergerak. Perluasan itu sudah diterima sebagai keniscayaan, bahkan tidak pernah lagi dipersoalkan lagi dalam praktik.

Menempatkan atau menahan harta kekayaan tergugat yang berkedudukan sebagai debitur di bawah penjagaan pengadilan. Tujuannya, agar keutuhan barang itu tetap terjamin nilai dan keberadaannya sampai putusan memperolah kekuatan hukum tetap. Apabila tergugat tidak memenuhi pembayaran secara sukarela maka harta kekayaan tergugat yang disita tersebut dijual lelang, dan harga yang diperoleh dipergunakan untuk membayar utang atau ganti rugi yang dibebankan kepada tergugat. Sedang apabila gugatannya tentang sengketa milik atas barang tidak bergerak, sita jaminan yang diletakkan bertujuan untuk menjamin keutuhan dan keberadaan barang sehingga terpelihara selama proses pemeriksaan berlangsung. Dengan demikian, pada saat putusan telah berkekuatan hukum tetap, barang tersebut dapat dieksekusi rill dengan jalan mengosongkan atau membongkar bangunan yang ada di atasnya serta sekaligus menterahkan kepada penggugat.

\section{Objek Sita Jaminan}

Di dalam sengketa milik, terbatas atas barang yag disengketakan, mengenai hal ini sudah dijelaskan pada pembahasan prinsip pokok penyitaan. Kebolehan meletakkan sita jaminan atas harta kekayaan tergugat dalam sengketa hak milik atas benda tidak bergerak yaitu hanya terbatas atas objek barang yang diperkarakan dan tidak boleh melebihi objek 
Jurnal Ilmu Hukum

FAKULTAS HUKUM UMSU
Pelaksanaan Sita Jaminan...(Mhd. Teguh Syuhada Lubis)

Volume 4 Nomor 1, Januari-Juni 2019, 42-53 DOI: https://doi.org/10.30596/dll.v4i1.3163

tersebut. Pelanggaran atas prinsip itu, dianggap sebagai penyalahgunaan wewenang dan sekaligus merupakan pelanggaran atas tata tertib beracara, sehingga penyitaan itu dikategorikan sebagai undue process atau tidak sesuai dengan hukum acara.

\section{Terhadap objek dalam sengketa utang atau ganti rugi}

Objek sita jaminan dalam perkara utang-piutang atau ganti rugi dapat diterapkan alternatif berikut:

a. Meliputi seluruh harta kekayaan tergugat

Sepanjang utang atau tuntutan ganti rugi tidak dijamin dengan agunan tertentu, sita jaminan dapat diletakkan di atas seluruh harta kekayaan tergugat. Pelaksanaan yang demikian bertitik tolak dari ketentuan Pasal 1131 KUHPerdata jo. Pasal 227 ayat 1 HIR, yang menegaskan:

1) Segala kebendaan debitur baik yang bergerak maupun yang tidak bergerak, menjadi tanggugan untuk segala perikatan perseorangan (Pasal 1131 KUHPerdata).

2) Barang debitur (tergugat) baik yang bergerak dan tidak bergerak dapat diletakkan sita jaminan untuk pembayaran utangnya atas permintaan kreditor (penggugat).

Kebolehan menyita seluruh harta milik tergugat dalam sengketa utang atau ganti rugi harus memperhatikan prinsip yang digariskan Pasal 197 ayat 8 HIR, Pasal 211 RBG:

1) Dahulukan penyitaan barang bergerak, jadi yang pertama-tama disita, barang bergerak. Apabila nilai barang bergerak yang disita mencukupi untuk melunasi jumlah gugatan, penyitaan dihentikan sampai disitu saja.

2) Kalau barang bergarak tidak mencukupi jumlah tuntutan, baru diporbolehkan melatakkan sita jaminan terhadap barang tidak bergerak, memperhatikan tata tertib penyitaan tersebut, dilarang langsung menyita barang tidak bergerak, jika tergugat memiliki barang bergerak. Namun, apabila sama sekali tidak ada barang yang bergerak, barulah dapat langsung disita barang tidak bergerak.

3) Terbatas pada barang agunan; jika perjanjian utang-piutang dijamin dengan agunan barang tertentu:

4) Sita jaminan dapat langsung diletakkan di atasnya meskipun bentuknya barang tidak bergerak

5) Dalam perjanjian kredit yang dijamin dengan agunan barang tertentu, pada barang itu melekat sifat spesialitas yang memberi hak separatis kepada kreditor, oleh karena itu prinsip mendahulukan penyitaan barang bergerak disingkirkan oleh perjanjian kredit yang dijamin dengan agunan.

Sita jaminan atas benda bergerak dapat terjadi apabila perjanjian kredit tidak dijamin dengan agunan barang tertentu atau jaminannya berbentuk fidusia. Penjelasan tentang hal itu, tidak memerlukan uraian lagi, karena pada dasarnya sama dengan prinsip umum yang dijelaskan pada prinsip-prinsip pokok penyitaan. Sedang tata caranya sama dengan pelaksanaan sita revindikasi. Namun demikian, terdapat beberapa hal yang perlu diingatkan, antara lain: 
DEIFGA IATA

Jurnal Ilmu Hukum

FAKULTAS HUKUM UMSU
Pelaksanaan Sita Jaminan...(Mhd. Teguh Syuhada Lubis)

Volume 4 Nomor 1, Januari-Juni 2019, 42-53 DOI: https://doi.org/10.30596/dll.v4i1.3163

1) Barang sitaan tetap diletakkan pada tempat semula, boleh dipindahkan ke tempat yang lain Dengan syarat, apabila hal itu perlu untuk keamanan dan keselamatan barang.

2) Penjagaan dan penguasaan diserahkan kepada tergugat (tersita). Tidak boleh diserahkan penjagaan dan penguasaannya kepada penggugat juga dilarang menyerahkan penjagaan dan penguasaannya kepada pihak ketiga atau kepala desa.

3) Tidak boleh diletakkan sita jaminan atas permintaan penggugat lain seperti yang dijelaskan, khusus terhadap penyitaan barang bergerak berlaku asas yaitu Saisie sur saisie ne vaut yang digariskan Pasal $463 \mathrm{Rv}$, yaitu pada saat yang bersamaan tidak boleh diletakkan sita terhadap barang yang sama. Yang dapat dilakukan atas permintaan sita yang belakangan adalah sita penyesuaian dengan jalan membuat berita acara penyesuaian (process verbaal van vergelijkende beslag)

4) Secara kasuistis dapat di bebankan jaminan kepada penggugat secara kasuisitis dapat diterapkan ketentuan Pasal $722 \mathrm{Rv}$ dalam pelaksanaan sita jaminan. Menurut pasal tersebut. Pengabulan sita jaminan yang diminta penggugat dibarengi dengan perintah atau persyaratan, sita jaminan baru dilaksanakan apabila penggugat membayar biaya, serta kerugian dan bunga yang mungkin timbul akibat penyitaan tersebut. Dalam hal yang demikian penyerahan uang jaminan, harus diberikan bersamaan dengan perintah penyitaan Mengenai berapa besarnya uang jaminan yang harus diberikan penggugat atas penyitaan itu, dapat ditetapkan pengadilan melalui sidang insidentil. Seperti yang telah dijelaskan, ketentuan ini dapat diterapkan secara kasuistis. Oleh karena itu ketentuan Pasal 722 Rv, tidak boleh dijadikan sebagai syarat yang bersifat generalisasi terhadap setiap penyitaan barang bergerak.

5) Tersita berhak mengajukan bantahan. Pasal $724 \mathrm{Rv}$ memberi hak kepada tergugat (tersita) untuk segera mengajukan bantahan terhadap sita jaminan yang diletakkan terhadap barang bergerak. Bantahan dapat diajukan di luar sidang atau dalam sidang insidentil. Dapat juga diajukan dalam proses pemeriksaan pokok perkara.

Tidak terdapat perbedaan pokok mengenai tata cara pelaksanaan sita jaminan atas barang bergerak dan barang tidak bergerak. Dengan demikian, tidak berbeda dengan tata cara pelaksanaan sita revindikasi, uraian yang dikemukakan pada bagian itu, berlaku juga dalam hal ini. Selanjutnya, penjelasan tambahan yang dikemukakan dalam sita jaminan barang bergerak meliputi juga terhadap sita jaminan barang tidak bergerak.

Agar terdapat kepastian hukum mengenai hasil yang timbul dari objek sita jaminan yang melekat padanya dan akan dibayarkan kepada penggugat bersama-sama dengan hasil penjualan barang sita jaminan, pengadilan harus mempertimbangkan dan menegaskannya dalam penerapan sita. Sita Jaminan di Tangan Pihak KetigaPenyitaan barang tergugat yang berada di tangan pihak ketiga disebut conservator beslog onder derden atau disingkat derden beslag. Dalam praktik dan penulisan disingkat dengan sita pihak ketiga. Tujuannya memberi hak kepada penggungat untuk mengajukan penyitaan terhadap hak milik tergugat yang berada di tangan pihak ketiga, untuk melindungi kepentingan kreditor (penggugat), agar terjamin pemenuhan pembayaran yang dituntut. Ada beberapa hal yang perlu diperhatikan terkait sita 
DEIFGA IATA

Jurnal Ilmu Hukum

FAKULTAS HUKUM UMSU
Pelaksanaan Sita Jaminan...(Mhd. Teguh Syuhada Lubis)

Volume 4 Nomor 1, Januari-Juni 2019, 42-53 DOI: https://doi.org/10.30596/dll.v4i1.3163

jaminan pada pihak ketiga.

b. Pengaturan

Ketentuan mengenai sita pihak ketiga diatur dalam Pasal 197 ayat 8 HIR dan Pasal 211 RBG dapat diletakkan sita meskipun barang-barang itu berada di tangan pihak ketiga. Ketentuan Pasal 197 ayat 8 HIR tersebut dasarnya berkenaan dengan sita eksekusi terhadap pihak ketiga (executorial beslag order derden). Namun, ketentuan tersebut berlaku dan diterapkan pada sita jaminan terhadap pihak ketiga (conservator beslag onder derden), karena Pasal 227 ayat 3 HIR memuat penegasan yaitu aturan tata cara pelaksanaan sita jaminan, tunduk kepada ketentuan Pasal 197, 198, dan 199 HIR (M. Yahya Harahap, 2008, h. 406).

c. Syarat Permintaan Sita Pihak Ketiga

Syarat yang mesti dipenuhi agar dapat diletakkan sita kepada pihak ketiga, dijelaskan dalam Pasal 728 Rv.

d. Barang objek sita pihak ketiga

Mengenai barang apa saja yang dapat dijadikan objek sita pihak ketiga, disebut dalam Pasal 197 ayat 8 HIR maupun Pasal 728 Rv, yang terdiri dari:

1) Uang tunai.

2) Surat berharga (commercial paper), seperti bill of change, promissory note, cheque, bond, money order dan sebagainya.

3) Tagian atau utang pihak ketiga kepada tergugat.

4) Penyitaan Berdasarkan Perintah.

Ketentuan ini diatur dalam Pasal 197 ayat 1 HIR, bahwa setiap penyitaan harus berdasarkan surat perintah yang dikeluarkan pengadilan. Ketentuan tersebut merupakan salah satu prinsip pokok penyitaan dalam segala bentuk. Oleh karena itu, sita pihak ketiga yang tidak didukung surat penerapan, tidak memiliki dasar hukum.

Pemberitahuan sita pihak ketiga, meliputi dua pihak:

1) Pemberitahuan kepada pihak ketiga

Hal ini diatur dalam Pasal 730 Rv, jika juru sita hendak menjalankan sita pihak ketiga atas barang milik tergugat yang ada di tangannya, tindakan itu harus diberitahukan kepada kantor:

a) Penyimpanan atau pemegangnya.

b) Kepada penyimpanan kas atau rekening.

c) Surat pemberitahuan penyitaan itu:

a.1. Ditandatangani pihak ketiga tersebut

b.1. Penandatanganan secara formil dikategorikan sebagai tindakan mengetahui.

d) Kalau penyitaan pihak ketiga dilakukan kepada perorangan, pemberitahuan langsung disampaikan kepadanya

e) Apabila pihak ketiga menolak menandatangani asli surat pemberitahuan, juru sita membuat catatan atas penolakan itu. 
DEIEGA LATA

Jurnal Ilmu Hukum

FAKULTAS HUKUM UMSU
Pelaksanaan Sita Jaminan...(Mhd. Teguh Syuhada Lubis)

Volume 4 Nomor 1, Januari-Juni 2019, 42-53 DOI: https://doi.org/10.30596/dll.v4i1.3163

2) Pemberitahuan kepada Tergugat

Selain pemberitahuan kepada pihak ketiga, Pasal $731 \mathrm{Rv}$ mewajibkan penyampaian pemberitahuan penyitaan kepada tergugat (debitur).

\section{Pelaksanaan Sita Jaminan Terhadap Objek Sengketa Yang Berada Di Tangan Pihak Ketiga Pada Perkara Perdata}

Pembahasan kali ini Pasal 227 HIR/261 RBG menentukan bahwa "Jika terdapat sangkaanyang beralasan bahwa tergugat akan menggelapkan atau memindahtangankanbarang miliknya dengan maksud akan menjauhkan barang tersebut daripenggugat, maka atas permohonan penggugat, pengadilan dapat memerintahkanagar diletakkan sita atas barang tersebut untuk menjaga/menjamin hak dari sipenggugat". Sepatutnya pihak yang berwenang menilai adanya persangkaan yangberalasan adalah hakim dan bukan penggugat. Memang tergugat memiliki hakmengajukan fakta tentang adanya persangkaan, tetapi kewenangan penilaianakhirnya tetap terletak di tangan hakim.

Secara tegas tentang penjagaan sita atas harta yang tidak bergerakmisalnya tanah tidak ada diatur dalam undang-undang. Undang-undang hanyamengatur mengenai penjagaan sita atas barang yang bergerak sesuai denganketentuan Pasal 197 ayat 9 HIR/212 RBG. Penyitaan atas benda tak bergerak,tidak boleh mengurangi hak tersita untuk memakai, menguasai dan menikmatinya.Rumah atau tanah yang disita, tetap berada di bawah penjagaan dan penguasaantersita, dan tersita tidak boleh dilarang untuk menguasai, memakai danmenikmatinya. Yang dilarang ialah untuk menjual atau memindahkannya kepadaorang lain sebagaimana termaktub dalam Pasal 199 HIR/214 RBG.

Berdasarkan penjelasan di atas maka barang sitaan tidak dilarang untuk tetapdikuasai, diusahai dan dinikmati pihak tersita (tergugat). Sejalan dengan ketentuanitu, undang-undang tidak memperkenankan penyerahan penguasaan ataupenjagaan barang sitaan benda yang tidak bergerak kepada penggugat.Penyerahan penguasaan atau penjagaan barang sitaan ke tangan penggugat, berarti hakim telah mengeksekusi perkara sebelum perkara yang bersangkutanmemperoleh kekuatan hukum yang tetap. Dalam kasus penyitaan terhadap harta di dalam putusan, penggugatmeminta sita jaminan dengan argumen tersendiri, yaitu agar gugatan penggugattidak menjadi sia-sia (ilusionis) serta dikhawatirkan adanya upaya para tergugatmelepaskan diri dari kewajibannya untuk membayar ganti kerugian yangdiputuskan oleh pengadilan.

\section{Tata Cara Pelaksanaan Sita Jaminan}

Mengenai tata cara pelaksanaan sita jaminan dijelaskan dalam Pasal 227 ayat 3 HIR. Tata caranya tunduk kepada ketentuan yang digariskan Pasal 197, 198 dan 199 HIR. Penegasan ini sama dengan yang diatur dalam Pasal 226 ayat 3 HIR yang menyatakan tata cara sita revindikasi mengikuti cara dan syarat yang digariskan Pasal 197 HIR. Bertitik tolak dari Pasal 226 ayat 3 HIR, tata cara dan syarat pelaksanaan sita jaminan dengan sita revindikasi, tunduk kepada ketentuan Pasal 197 HIR sepanjang objek sita jaminan adalah barang bergerak. Akan tetapi, apabila objeknya adalah barang tidak bergerak harus ditaati 
Jurnal Ilmu Hukum

FAKULTAS HUKUM UMSU
Pelaksanaan Sita Jaminan...(Mhd. Teguh Syuhada Lubis)

Volume 4 Nomor 1, Januari-Juni 2019, 42-53 DOI: https://doi.org/10.30596/dll.v4i1.3163

ketentuan Pasal 198 HIR, yaitu mendaftarkan dan mengumumkan berita acara penyitaan di kantor pendaftaran yang berwenang untuk itu.

Sehubungan dengan itu, oleh karena tata cara penyitaan revindikasi sama dengan sita jaminan maka tata cara penyitaan yang diuraikan pada sita revindikasi, berlaku seleruhnya pada sita jaminan yang terdiri dari:

a. Dilaksanakan berdasarkan penetapan pengadilan. Dituangkan dalam bentuk surat penetapan yang diterbitkan oleh ketua Pengadilan Negeri atau Majelis yang bersangkutan berisi perintah kepada panitera atau juru sita untuk melaksanakan sita jaminan terhadap harta kekayaan tergugat.

b. Penyitaan dilaksanakan panitera atau juru sita.

c. Memberitahukan penyitaan kepada tergugat yang berisi Hari, tanggal, bulan, tahun, dan jam serta tempat penyitaan agar tergugat menghadiri penyitaan, namun seperti yang telah dijelaskan, kehadiran tergugat tidak menjadi syarat keabsahan pelaksanaan sita.

d. Juru sita dibantu dua orang saksi. Dijelaskan nama, pekerjaan, dan tempat tinggal saksi dalam berita acara sita saksi harus penduduk Indonesia paling rendah berumur 21 tahun orang yang dapat dipercaya.

e. Pelaksanaan sita dilakukan di tempat barang terletak juru sita dan saksi datang di tempat barang yang hendak disita, dan tidak sah penyitaan yang tidak dilakukan di tempat barang terletak.

f. Membuat berita acara sita, hal-hal pokok yang harus dimuat dalam berita acara sita jaminan tanggal dan nomor surat penetapan jam, tanggal, hari, bulan, dan tahun penyitaan, nama, pekerjaan, dan tempat tinggal saksi, rincian satu per satu jenis barang yang disita, Penjelasan pembuatan berita acara dihadapan tersita (jika hadir), Penjelasan penjagaan barang sitaan diserahkan kepada tersita, dan ditandatangani juru sita dan saksi.

Berdasarkan urian di atas dengan adanya pencatatan tentang hal itu dalam berita acara, secara formil dan resmi pemohon berkedudukan sebagai pemegang sita penyesuaian, maka: Meletakkan barang sitaan di tempat semula; Menyatakan sita sah dan berharga (M. Yahya Harahap, 1990, h. 321)..

Demikian pokok-pokok tata cara dan syarat sita jaminan. Untuk memperoleh penjelasan yang lebih lengkap. HIR/RBG sama sekali tidak mengatur upaya hukum khusus bagi pihaktersita untuk melawan instrumen sita jaminan.Memang pada dasarnya sitajaminan tidak ditujukan untuk melakukan eksekusi/penjualan terhadap obyek sita dan sekedar melarang tersita untuk melakukan perbuatan hukum terhadap barang tersebut. Namun, sita jaminan tersebut tetap dapat menimbulkan kerugianterhadap tersita.Sebaliknya Rv justru memuat ketentuan yang secara khusus mengaturperlawanan terhadap sita jaminan, Pasal 724 dan 725 Rv memberikan kesempatanbagi tersita untuk mengajukan bantahan baik dengan sidang singkat di hadapanketua (pengadilan) maupun dihadapan sidangraad van justitie.Perlawanan inidiajukan dalam suatu pemeriksaan atas sah dan berharga atau tidaknya sitajaminan, yang harus diadakan 8 (delapan) hari setelah sita ditetapkan.

Mengenai tata cara pemberian sita penyesuaian, perlu diperhatikanPutusan Mahkamah 
Jurnal Ilmu Hukum

FAKULTAS HUKUM UMSU
Pelaksanaan Sita Jaminan...(Mhd. Teguh Syuhada Lubis)

Volume 4 Nomor 1, Januari-Juni 2019, 42-53 DOI: https://doi.org/10.30596/dll.v4i1.3163

Agung Nomor 1326 K/Sip/1981 tanggal 19 Agustus 1982 yang menyebutkan jika barang yang hendak disitajaminankan telah disita dalamperkara lain, atau telah dijaminkan kepada orang lain atau telah disita eksekusi,Pengadilan Negeri hanya boleh memberi dan melakukan sita penyesuaian(vergelijkende beslag) dengan jalan mencatat dalam berita acara bahwa barangyang bersangkutan telah dan sedang berada di bawah sita jaminan atau diagunkankepada pihak lain.

Cara untuk mengetahui status barang sedang berada di bawah penyitaan atau agunan dapat diperoleh dari berbagai sumber antara lain: (M. Yahya Harahap, 1990, h. 321)

1. Berdasarkan pengetahuan hakim atau juru sita sendiri yang bersumber dari berita acara sita yang ada di pengadilan, atau

2. Dari keterangan tergugat sendiri di dalam atau di luar persidanganberdasarkan dokumen berita acara sita atau perjanjian kreditBilamana ditemukan fakta tentang status barang yang sedang berada dalampenyitaan atau diagunkan, permohonan yang dapat diajukan terhadapnya adalahsita penyesuaian, bukan bentuk sita yang lain. Dengan adanya pencatatan tentanghal itu dalam berita acara, secara formil dan resmi pemohon berkedudukan sebagai pemegang sita penyesuaian

\section{KESIMPULAN DAN SARAN \\ Kesimpulan}

Pengaturan Pelaksanaan Sita Jaminan Objek Sengketa Yang Berada Di Tangan Pihak Ketiga Pada Perkara Perdata diatur dalam Pasal 197 ayat 8 HIR dan Pasal 211 RBG. Ketentuan Pasal 197 ayat 8 HIR tersebut dasarnya berkenaan dengan sita eksekusi terhadap pihak ketiga (executorial beslag order derden). Namun, karena Pasal 227 ayat 3 HIR memuat peneasan yaitu aturan tata cara pelaksanaan sita jaminan, tunduk kepada ketentuan Pasal 197, 198, dan 199 HIR. Pelaksanaan Sita Jaminan Pada Objek Sengketa Yang Berada Di Tangan Pihak Ketiga Penyitaan barang tergugat yang berada di tangan pihak ketiga disebut conservator beslog onder derden atau disingkat derden beslag. Dalam praktik dan penulisan disingkat dengan sita pihak ketiga. Tujuannya memberi hak kepada penggungat untuk mengajukan penyitaan terhadap hak milik tergugat yang berada di tangan pihak ketiga, untuk melindungi kepentingan kreditor (penggugat), agar terjamin pemenuhan pembayaran yang dituntut.Sehubungan dengan itu, oleh karena tata cara penyitaan revindikasi sama dengan sita jaminan maka tata cara penyitaan yang diuraikan pada sita revindikasi, berlaku seluruhnya pada sita jaminan yang terdiri dari dilaksanakan berdasarkan penetapan pengadilan, Penyitaan dilaksanakan panitera atau juru sita, Memberitahukan penyitaan kepada tergugat, Juru sita dibantu dua orang saksi, Pelaksanaan sita dilakukan di tempat barang terletak, membuat berita acara sita, Meletakkan barang sitaan di tempat semula, Menyatakan sita sah dan berharga.

\section{Saran}

Di dalam rangka pelaksanaan Sita Jaminan Objek Sengketa Yang Berada Di Tangan Pihak Ketiga Pada Perkara Perdata terkait dengan peraturannya harus dapat lebih dipahami dengan jelas oleh para penegak hukum yang bertugas melaksanakannya. 


\section{DAFTAR PUSTAKA}

Harahap, M. Yahya. (1990). Permasalahan dan Penerapan Sita Jaminan (Conservatoir Beslag). Bandung: Pustaka.

Harahap, M. Yahya. (2008). Hukum Acara Perdata. Jakarata: Sinar Grafika.

Sarwono. (2011). Hukum Acara Perdata Teori dan Praktek. Jakarta: Sinar Grafika.

Soeparmono, R. (2006). Masalah Sita Jaminan dalam Hukum Acara Perdata. Bandung: Mandar Maju.

Sutanto, Retnowulan., \& Oeripkartawinata, Iskandar. (2009). Hukum Acara Perdata dalam Teori dan Praktek. Bandung: CV Mandar Maju. 